\title{
Folyamat-innovációs eszközök és stratégiák a termelésmenedzsment területén
}

\section{Process innovation tools and strategies in production management}

\author{
E. ERDEI
}

Debreceni Egyetem Ihrig Károly Gazdálkodás- és Szervezéstudományok Doktori Iskola, edina.erdei@econ.unideb.hu

Absztrakt. Folyamat-innováció módszere segít megvalósítani a termelési folyamatokban azokat a lehetőségeket, amelyek egyértelmü versenyelőnyt jelentenek. Alkalmazásával akár $30 \%$ feletti változás is elérhető a termelékenység növekedésében, valamint a költségek, készletek és átfutási idők csökkentésében. A folyamatfejlesztés során nincs szükség bonyolult módszerekre. A mindenki által használható, logikus, egyszerü eszközök ereje abban rejlik, hogy mindenki képes megtanulni, megérteni, alkalmazni, és gyors visszacsatolást adni a müködésről. A napjainkban nyújtott lehetőségek jelentős változást hoztak a gyártórendszerek kialakításában, müködtetésében. $A$ kiberfizikai rendszerek megjelenése, a big data nyújtotta lehetöségek és a „dolgok internete” (Internet of Things) eröteljes kutatási potenciált jelenítettek meg a logisztikai, gyártási rendszerek hatékonyabb múködtetésében. A hálózati együttműködésben rejlő lehetőségek, a gyártásban áramló anyagok nyomkövetéséből származó információk és a gépek közötti kommunikáció a gyártási folyamatok széleskörü optimalizálására adnak lehetôséget. A kutatás során bemutatott eszköztár nem csak a közvetlen termelésben használható, hanem az értékteremtő folyamat majdhogy nem minden része felbontható rutinszerü cselekvések sorrendjére, így a problémák okai elemezhető és a folyamat egyes részeinek fejlesztése könnyebben megvalósítható.

Abstract. The method of process innovation helps to recognize the opportunities in production processes that represent clear competitive advantage. Using it, up to $30 \%$ change is available in increasing productivity and in the reducing of costs, stocks, and lead times. There is no need for complicated methods in the process development. The power of logical, simple tools relies on the fact that everyone can learn, understand, apply them and give quick feedback about their operation. Significant changes have been made in today's possibilities of designing and operating production systems. The emergence of cyber physical systems, the opportunities offered by big data, and the "Internet of Things" (Internet of Things) have shown strong research potential for more efficient logistics and manufacturing systems. The potential of network co-operation, information gathered from tracing materials in production and communication between machines provide a wide-range of optimization opportunities for manufacturing processes. The toolkit presented in the research cannot only be used in direct production; almost all parts of the value creation process can be broken down into routine actions, so the causes of the problems can be analyzed and the development of the process' parts can be easier implemented. 


\section{Bevezetés}

Napjainkban egyre több vállalatnál fedezik fel az anyagi folyamatok jelentőségét. A logisztika és a folyamatszemlélet, fogyasztói igények növekedése és gyors változása, az elfogadható minőség, a rugalmasság és a gyorsaság fontosságát eredményezte. A termelés szerepe stratégiai fontosságúvá vált ebben a versenyben. A vevők által megkövetelt termékminőség biztosítása csupán a megfelelő logisztikai folyamatok és gyártási technológiák kialakításával érhető el.

Ahhoz, hogy a vállalatok megtartsák, illetve növeljék versenyelőnyüket a folyamatos fejlesztés mind a logisztika, mind pedig a gyártás területén elengedhetetlenné vált. A tömeggyártással szemben az egyedi gyártás minél hatékonyabb megvalósítása a cél. Azok a vállalatok válnak sikeressé, melyek az egyedi vevői igények alacsony költségen való kielégítésére képesek.

A folyamat-innováció a kis- és közepes vállalatoknál is kulcsfontosságú, mivel hatékonysággal, gyorsasággal, valamint ügyfélorientált szemlélet kialakításával lehetnek versenyképesek. Egy multinacionális vállalat esetén a méretgazdaságosság, tőkeellátottság is befolyásolja a versenyelőnyt, viszont egy közepes vállalatnál sokszor a munkavégzés módjában, az üzleti folyamatokban rejlik a versenyelőny, melynek megvalósítása innovatív megközelítést igényel. Sok esetben a folyamatinnováció a meglévő folyamatok részterületeinek újragondolását jelenti. A versenyelőnyök megtalálásához és megvalósításához a munkavégzés új módjainak kialakítására van szükség, amely nem nélkülözheti a korábbi tapasztalatokat az innovációs képességet és kreativitást.

Folyamatfejlesztési tevékenységre többnyire a minőség javítása vagy a hatékonyság növelése érdekében kerül sor. A folyamat innováció filozófiája az, hogy nincs olyan minőségi színvonal, olyan gyártási folyamat, amelyen ne lehetne javítani. Ennek a filozófiának az elismert képviselője Japán, ahol a folyamatos fejlesztés már több mint harminc éve működik a Just in Time részeként. Ennek ellenére minden évben nő a fejlesztésre tett javaslatok száma. Japánban 1988-ban egy átlagos dolgozó évi 24 javaslattal állt elő és ezek 82\%-át a gyakorlatban is megvalósították. Az USA-ban éves szinten átlagosan egy dolgozó 0,16 javaslattal állt elő, melynek csak a 22\%-át valósították meg.

A problémamegoldáshoz kapcsolódó módszerek (Pareto-hatékonyság, szabályozási táblák, Ishikawadiagram, stb.) és az új lehetőségek (Internet of Things, kiberfizikai rendszerek, Big Data, stb.) nagy hatással vannak a gyártási, logisztikai rendszerek kialakításában és fejlesztésében. A folyamat teljes megismerése után kerülhet sor a fejlesztésre. Ennek néhány eszközét mutatják be a következő fejezetek.

A kutatás fő kérdése az, hogy az ismertetett IT-fejlesztések hatással vannak-e a vállalkozások árbevételére és a rugalmasságra? A következő fejezetekben az elméleti háttér ismertetése után megvizsgáljuk, hogy van-e összefüggés az informatikai fejlesztések és a gyártó vállalkozások sikere között. 


\section{Szakirodalmi áttekintés}

Az informatika és az információs és kommunikációs technológiák fejlesztése folyamatos és megállíthatatlan [1]. Wu et al. (2006) tanulmányozta az informatika hatását az ellátási láncok teljesítményére [2]. Megállapítása szerint a vállalkozások folyamatosan növekvő informatikai támogatást vesznek igénybe, hogy továbbfejlesszék folyamataikat. Az IT-befektetések nem feltétlenül garantálják a vállalati teljesítmény növekedése, hiszen ezen készségek az egyes szervezetek között nehezen reprodukálhatók.

Jelenleg a robotok alkalmazása az ipari gyakorlatban csak tömegtermelés esetén gazdaságos. A robotok megvalósítása az egyedülálló termelési rendszerek számára fontos lehetőség, intelligens rendszerként képes hibákat azonosítani még a hibák eredőjeként is, így lehetővé teszi a késedelem elkerülését és a műveletek pontosságának növelését [3].

A technológiai folyamatok innovációján az új, vagy jelentősen megújított termelési módszerek alkalmazását értjük. A módszerek magukba foglalhatják az egész termelési részleg átalakítását, a gépek kicserélését és az új tapasztalatok felhasználását. Ezen módszerek legfőbb célja olyan szolgáltatások nyújtása és technológiailag újragondolt vagy kifejlesztett termékek előállítása, melyek a közönséges, eddig használt eljárásokkal nem teljesíthetők. Fontos, hogy olyan rendszereket vezessenek be, amivel lényegesen növelhető a már létező termékek szállításának és elóállításának hatékonysága. A vállalat folyamat-innovációs tevékenysége elsősorban az alábbi esetekben javasolt:

- Új üzleti tevékenységek létrehozásakor.

- A működés hatékonyságának növeléshez.

- Ügyfélorientált üzleti folyamatok újraszervezésekor.

- Integrált vállalatirányítási rendszer bevezetésekor vagy hatékonyabb hasznosítása érdekében.

- Az egész vállalat eredményességének növelésekor.

Az FMEA (Failure Mode and Effect Analysis) a hibamódok azonosítására és a hiba hatásának elemzésére szolgál [4]. A termék elkészítése során a fejlesztés-tervezés fázisban és a gyártásban, szolgáltatásban ténylegesen fellépő hibák azonosítására és elemzésére használható módszer. A hagyományos FMEA-nak három típusa van: a tervezés, koncepció és folyamat [5]. Célja, hogy javítsák és csökkentsék a felmerülő problémákat és azokat hatásuk alapján rangsorolják. A sorrend megállapítása az egyes szakmai csoportok feladata. A következő paraméterek hozzá vannak rendelve a felmerülő problémák okaihoz:

- $\mathrm{S}$ = a meghibásodás súlyossága.

- = az előfordulás gyakorisága.

- $\quad \mathrm{D}=\mathrm{a}$ hiba észlelhetősége.

- $\quad \mathrm{RPN}=\mathrm{S}^{*} \mathrm{O} *$ D. [3] 
A Pareto-diagram segítségével megtalálhatók azok a tényezők, amik a leggyakrabban előforduló problémákat idézik elő és a legjobban befolyásolják a folyamat egyes részeit. Használatakor szükség van a befolyásoló tényezők és problémák lehetséges csoportjainak meghatározására. A Pareto elv nevét Wilfredo Pareto, olasz tudóstól kapta, aki arra a megállapításra jutott, hogy Milano lakosságának 20\%-a kezében összpontosul a város vagyonának 80\%-a. Az elemzés tehát a $\mathbf{8 0 / 2 0}$ szabályon alapszik, vagyis a problémák 80\%-a mögött a kiváltó okok 20\%-a áll [6]. A Pareto elv azon fontosabb problémáknak a kiválasztására ajánlott, amelyek megoldásától a legnagyobb eredményeket várhatjuk. Tehát érdemes rangsorolni a problémákat és először a lényeges $20 \%$-kal kell kezdeni az újratervezést. A Pareto-diagram, egy olyan oszlopdiagram, amely a hibás adatokat a legnagyobb gyakoriságútól a legkisebb felé haladva ábrázolja (1. ábra).

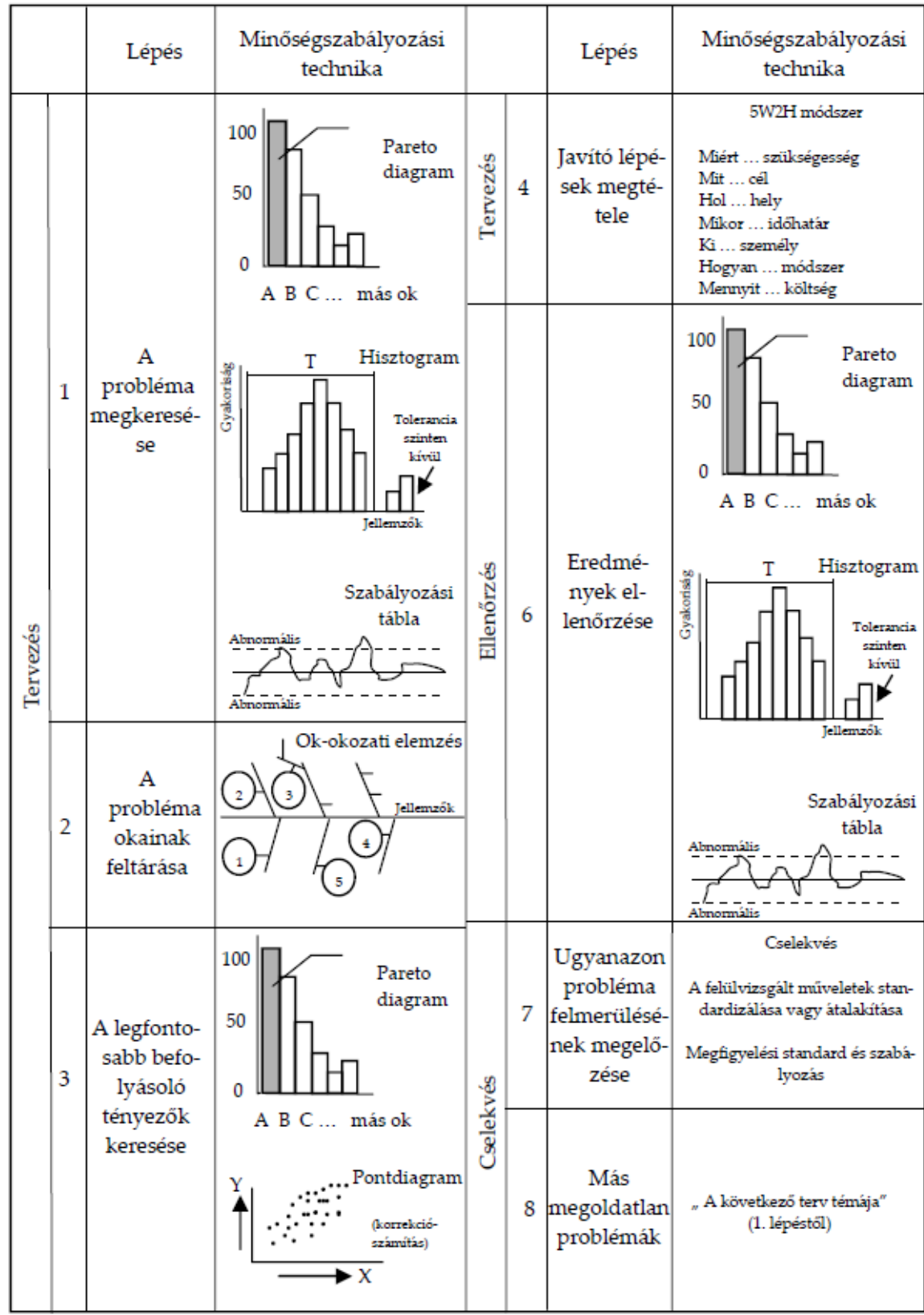

1. ábra: A problémamegoldás és a folyamatos fejlesztés eszközei Forrás: [7]. 
A Pareto-elemzéssel kiválasztott problémákat okozatnak tekintjük, és megkeressük azokat az okokat, amelyek ezeket a gyengeségeket kiváltják. Ez a folyamat az ok-okozati elemzés, másnéven Ishikawadiagram. A cél a legvalószínűbb okok meghatározása. Az eredmény után, ha kiderül, hogy az ok nem realisztikus, azaz tényekkel nem támasztható alá kellőképpen, akkor a folyamatot a már tovább bővített vagy egy teljesen új adatbázison ismét végre kell hajtani. Az elemzés akkor nevezhető sikeresnek, ha kellően megalapozott és így valós okok definiálásához vezet. Számos és jelentős okot tárhatunk fel az Ishikawa-diagram elkészítésével [8]. Miután bizonyítottuk ezen okok valós és jelentős voltát, az okokat meg kell szüntetni. Célszerű újabb minőségi elemzésnek alávetni a javított terméket vagy folyamatot, hogy ezáltal ellenőrizni tudjuk, hogy megszűnt-e az okozat, valamint ki tudjuk szűrni, hogy nem keletkeztek-e más hibák a beavatkozás során.

A hisztogram egy egyszerű statisztikai eszköz, amely a minta elemzését segíti azáltal, hogy a gyưjtött adatok (minta) alapján lehetőséget ad következtetések levonására. Ha túl nagy mennyiségü érték jelentkezik, akkor osztályokba vonják össze őket. A hisztogram valójában egy olyan oszlopdiagram, amely X-tengelyén a tulajdonság osztályok szerepelnek, vagyis egy változó különböző értékei, Ytengelyén pedig az előfordulási gyakoriságok találhatóak. A hisztogram megmutatja a diszkrét vagy a folyamatos eloszlás alakját, terjedelmét és középértékét [9]. Ezáltal meg tudjuk mondani egy folyamatról vagy egy rendszerről, hogy mennyire képes kielégíteni bizonyos követelményeket. Minőség és problémaelemzés során, a gyakorlatban általában folyamatos eloszlást mutató paraméterek megjelenítésénél használjuk (azoknál a paramétereknél, amik diszkrét eloszlást mutatnak pl.: hibák száma a Pareto-diagramot használjuk), a diagram alakja a minták eloszlását szemlélteti, amiből a mintára vonatkozó következtetéseket tudunk levonni.

Folyamat-innovációs eszköznek tekinthetők a pontdiagram függvények, melyeket eloszlások definiálására és szemléltetésére használnak, egy koordináta-rendszerben felrajzolt pontokból álló ábra formájában. Ez úgy valósul meg, hogy a változók közötti kapcsolatot a pontok tömörülése, szétszóródása, illetve az elhelyezkedési módja mutatja meg. A pontdiagramok két adatsor számértékeinek kapcsolatát szemléltetik, illetve két számcsoportok ábrázolhatunk a koordináták sorozataként. Ez a diagramtípus kiválóan alkalmazható tudományos adatok ábrázolására.

Eredményes problémamegoldást érhetünk el az 5W2H módszerrel. Elnevezése a módszer alapját alkotó angol kérdőszavak kezdőbetűiből alakult ki:

- what - mit,

- who - ki,

- where - hol,

- when - mikor,

- why - miért,

- how - hogyan

- how much - mennyit. 
Gyakran 5W1H ként találkozunk vele, mivel az utolsó H csak később került a listára. Első lépéskent meghatározzuk az ideális állapottól való eltérést, majd az 5 miért módszerrel megkeressük a gyökérokot [10].

Kétszámjegyű százalékos változás érhető el a folyamat-innovációhoz kötődő fejlesztésekkel az alábbi területeken:

- Egyéni és csoport szinten nő a termelékenység.

- Hatékonyabb likviditás és készletcsökkentés.

- Költségcsökkentés.

- Szervezési és pénzügyi előnyök.

- Csökken az átfutási idő.

Mindezek hatásaként létrejön egy sokkal hatékonyabb és versenyképesebb vállalat.

\section{Fejlődés és növekedés Magyarországon}

A hazai vállalatvezetők ma már sokkal nagyobb technológia változásra számítanak, mint az elmúlt években, a megkérdezettek 62\%-a gondolta úgy, hogy a technológia a jövőben hatással lesz piaci versenyre. Ma már szinte nincs olyan vállalatvezető, aki ne úgy gondolná, hogy a következő években az üzletmenetet érintő átalakulások jelentős részénél az újabb és újabb technológiák bevezetésének ne lenne szerepe. Világszerte, így Magyarországon is a humán erőforrás fejlesztése, digitális és technológiai képességek megjelenése és a folyamatos innováció tűnik a jövő kulcsának [11].

A vezérigazgatókat továbbá a szakemberhiány aggasztja a legnagyobb mértékben, hiszen ennek kezelésével ma már szinte majdnem minden vállalat, szervezet foglalkozik, amikor is megfogalmazzák az elvárást, hogy az alkalmazkodó és képzett munkaerő rendelkezésre állása kormányzati prioritás kellene, hogy legyen. A vezetők szerint globálisan és Magyarországon az együttmúködés, az alkalmazkodóképesség és a problémamegoldás a legfontosabb és keresendő készségek. Magyarországon a magántulajdonban lévő vállalkozások, illetve a távközlési és a technológiai területeken működő vállalkozásokat munkaerő-felvételi tervei a legambiciózusabbak. Magyarországon mindössze 13\% tervez létszámcsökkentést a megkérdezettek közül [11].

Magyarországon a gyártási folyamat legfontosabb sikertényezői az informatikai fejlesztések és a rugalmasság, melyek hatással vannak a pénzügyi eredményekre [12].

\section{Folyamat-innovációs eszközök jelentősége}

Az 1. táblázat tartalmazza a 4 legtöbbször előforduló hibát és azok súlyosságát. Az $\mathrm{S}$ oszlopban található értékek a meghibásodások súlyosságát jelentik. A mutatószám a problémák bekövetkezésekor a hibák következményeit értékeli 1-től 10-ig terjedő skálán pontozással. Az 0 oszlop az előfordulás gyakoriságát mutatja szintén 1-től 10-ig terjedő skálán pontozással, ami megmutatja, hogy mekkora annak a valószínúsége, hogy a bekövetkezett probléma meghibásodást okoz. A D oszlop 
pedig a hiba észlelhetőségét tartalmazza, vagyis azt, hogy a jelenlegi ellenőrzések, intézkedések, tesztelések mennyire hatékonyak. Ezt a szempontot is szintén 1-től 10-ig pontozzák. Ezen oszlopok szorzata adja az RPN értéket, mely egy kockázat prioritási számot jelöl. Ha az RPN értéke kisebb, mint 40, akkor a kockázat elfogadható, nincs szükség intézkedésre. Ha az RPN értéke nagyobb, mint 40, de kisebb, mint 100, akkor az adott hiba felülvizsgálatára van szükség. Ha az RPN értéke nagyobb, mint 100, akkor a kockázat már nem elfogadható, intézkedés szükséges. A túl kevés/sok alapanyag kimérés és a fagyasztás nagy üzemeltetési idejét felül kell vizsgálni.

A FMEA módszer szerint a rossz kezdeti alapanyag kimérés oka a manuális, azaz a nem gépi kimérésben keresendő. A dolgozó hol többet, hol pedig kevesebben mér ki az adott adalékanyagból, oly annyira, hogy az már az elő́rásoknak nem felel meg, ezért hulladéknak tekinthető. Ezzel a hibával nagyobb összegű anyagi kár keletkezhet. A formázás során a rossz méretek megadásából keletkező problémák a becsomagolt termékek végső súlyát befolyásolhatja. A méret helytelen beállítása figyelmetlenségből adódhat. A kutatás során ilyen jellegű probléma a termékek $5 \%$-ánál fordult elő. A gyártás során a legtöbb időt a termék a fagyasztóban tölti, melynek fenntartási költsége nagyon magas, ezért ennek az optimalizálása az egyes termékek esetén elengedhetetlen. A fagyasztó felesleges üzemeltetési ideje jelenti a legnagyobb költséget a vállalatok számára. Fontos a csomagolóanyagok megfelelő minősége, mivel annak elszakadása a termékek meghibásodása mellett a vásárlók elvesztését jelentheti.

\begin{tabular}{|l|l|c|c|c|c|}
\hline \multicolumn{7}{|c|}{ Élelmiszergyártási folyamat } \\
\hline Folyamat lépése & \multicolumn{1}{|c|}{ Felmerülő hibák } & $\mathrm{S}$ & 0 & $\mathrm{D}$ & $\mathrm{RPN}$ \\
\hline Kimérése & Túl kevés/sok alapanyag kimérés & 8 & 5 & 6 & $\mathbf{2 4 0}$ \\
\hline Formázás & Nem jó méret & 6 & 4 & 4 & 150 \\
\hline Fagyasztás & Üzemeltetési idő nagy & 8 & 7 & 4 & $\mathbf{2 2 4}$ \\
\hline Csomagolás & Rossz minőség & 3 & 3 & 6 & 54 \\
\hline
\end{tabular}

1. táblázat: Az FMEA módszer használata a felmerülő hibák kezelésére

Forrás: Saját szerkesztés, 2018.

A termelési folyamat megbízhatóvá, hatékonnyá és gyorssá tehető, ha megfelelő technológiát alkalmaznak a fenti problémák megoldására. Az újszerű gépek bevezetése során azonosíthatjuk a kimért mennyiségek súlyát, a formázó gépek beállított méreteit. Ha eltérés van a megfigyelt és az előírt súly és méret között, akkor a berendezés segítségével a probléma időben észlelhető, ennek köszönhetően azonnal leállítható a folyamat. A hagyományos rendszerek esetén a termelési folyamat hibás termék gyártásakor nem áll le, ezért azt csak a csomagolás előtt veszik észre, ezáltal a gyártási költség nagyobb lesz. Az alábbi és a következő fejezetben található eszközök segítségével javíthatunk a gyártási folyamaton, ezáltal optimalizálhatjuk az időt és a felmerült költségeket.

A termelő vállalatoknak gyorsan kell reagálniuk a kereslet és kínálat változására. A fogyasztói elégedetlenség forrása lehet az udvariatlan kiszolgálás, a túl hosszú várakozási idő, a kis választék, a magas árak, a szűk hely stb. Ha a fogyasztók erről alkotott észrevételeit és véleményét összegyűjtjük, akkor rájöhetünk, hogy melyik az a terület, amin ha változtatunk, akkor a fogyasztók legnagyobb része 
elégedettebben távozik. A legnagyobb fejlődést a legproblémásabb területre fókuszálva érhetjük el ( 2 . ábra.).

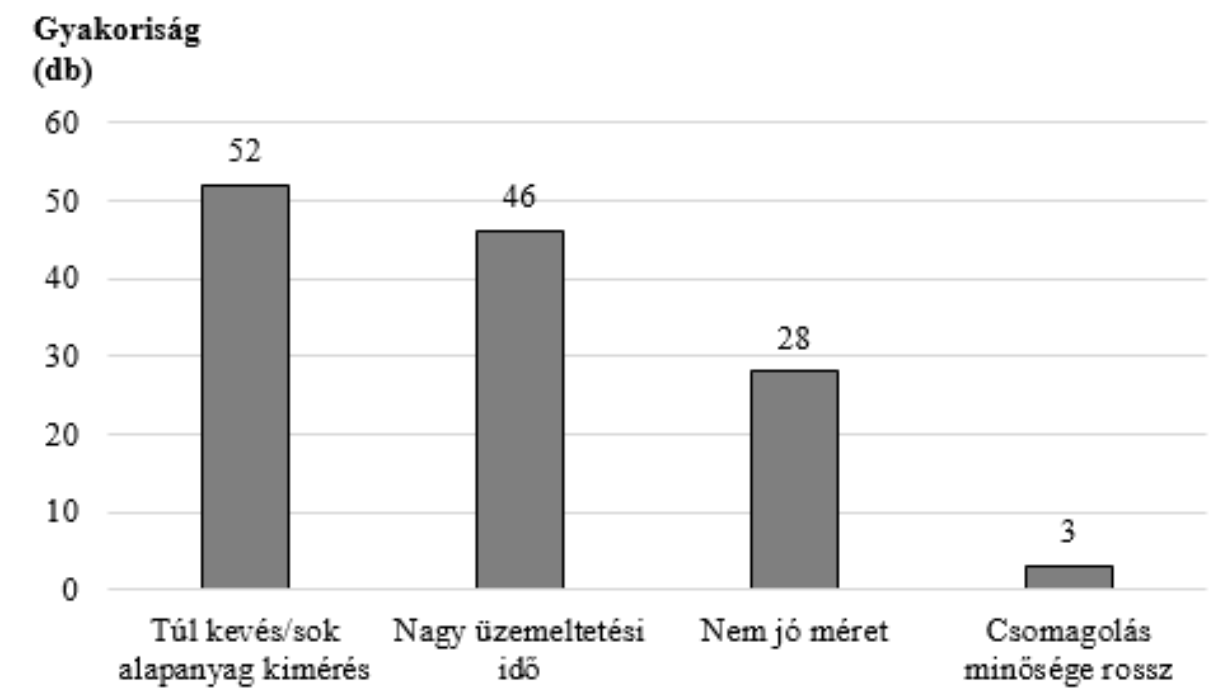

2. ábra: Pareto-diagram alkalmazása a problémás területek előfordulásának gyakoriságára Forrás: Saját szerkesztés, 2018.

A Pareto-diagramban a függőleges tengely az egyes problémák számosságát, míg a vízszintes tengely a problémák fajtáit jelenti. Ha kijelöltük a legnehezebb területet (például túl sok alapanyag kimérés), akkor a probléma lehetséges forrásainak felkutatása után vizsgálnunk kell a probléma keletkezésének fő okát. Ezek lehetnek: a hibás információáramlás, tapasztalatlanság, rossz minőségű vagy pontatlan mérleg stb. A tapasztalatok azt mutatják, hogy nem egyetlen ok vezet a következményhez, mégis előfordul néhány aspektusa a termelésnek, amelyek a fő okoknak. Ezen okok a Pareto-elemzés során kiszűrhetők.

A hisztogrammal jól elemezhetők a hibákból adódó eltérések mértéke és iránya, valamint a hibák gyakorisága. A hisztogram egy adott tulajdonság alakulását vizsgálja. A függőleges tengelyen az előfordulás gyakorisága szerepel, a vízszintes tengelyen a jellemző lehetséges értékei. Optimálisan működő termelési folyamat esetén a gyakoriságok normális eloszlást követnek, melynek a szélső értékei a toleranciaszinten belül helyezkednek el. Ez azt jelenti: minél csúcsosabb az eloszlás, annál jobb a folyamat.

A problémák okainak feltárására az ok-okozati diagram, másnéven Ishikawa-diagram is alkalmazható. Az Ishikawa elemzés célja: egy probléma vagy állapot összes lehetséges okának szisztematikus, növekvő részletességgel történő meghatározása és grafikus ábrázolása. A diagram gerince a problémát jelenti (pl. a csomagolópapír minősége), a szálkák pedig a problémát előidőző okcsoportokat taglalják, melyek a végső okokig bonthatók és végül valóban egy „hal csontváza” alakul ki az okok halmazából. Csak miután rendelkezésre állnak a lehetséges okok, akkor szabad továbblépni, és megkeresni a valódi problémát (a többi statisztikai eszközzel, vagy a helyzet ismeretében). Az ok-okozati diagram a probléma alapos ismeretét igényli. Csak akkor hasznos eszköz, ha hosszabb idő, alapos munka és jelentős érőforrás- és ráfordított idő áll mögötte, így megalkotói valóban teljesen körüljárják a lehetséges okokat. 
A szabályozási táblák alkalmazásával a hibaforrások könnyedén észlelhetők, ha a termék egyes jellemzőinek változását (pl. termék mérete, súlya) vizsgáljuk meg. A tábla felső és alsó szaggatott vonalai a toleranciaszintet mutatják, a középső egyenese pedig a jellemző elvárt értékét jelzi. A gyakorlat alapján, ha egy adott jellemző alakulását szemléltető görbe hét egymást követő alkalommal vagy a görbe alatt vagy a görbe fölött helyezkedik el, vagy az iránya hétszer egymás után az egyik irányba orientálódik, akkor a folyamatban valamilyen probléma van. A görbe a problémák feltárásán túl jól használható megelőző karbantartásra is. A kritikus jellemzők folyamatos figyelésével azonnal kiszűrhető a rendellenesség, ezért időben kijavítható a probléma.

A pontdiagram két jellemző módosulása közötti összefüggést keresi. A diagram tengelyein a két vizsgált jellemző lehetséges értékei szerepelnek. Ha az értékek valamilyen szabályosságot mutatnak, akkor a kapcsolatra vonatkozóan következtetést vonhatunk le.

Hatásos és egyszerű módszer az 5W2H, melynek hatékonysága abban rejlik, hogy az összes lehetséges kérdés megvizsgálásával a döntéshozót a probléma szisztematikus analizálására kényszeríti.

- Who? Ki végzi a tevékenységet? Csak az végezheti, aki jelenleg is foglalkozik vele? Kevesebb idő, vagy alacsonyabb képzettség is elég a tevékenység elvégzéséhez?

- What? Mit vár el a vásárló? A folyamat végrehajtásakor nem lehet néhány lépést egyszerűsíteni, összevonni vagy esetleg kihagyni? Minél nagyobb múltja van egy vállalatnak, annál nagyobb az esélye annak, hogy a folyamat során végrehajtandó tevékenységeket csak a megszokás miatt végzik el.

- Where? Ott van a szükség a feladatra, ahol azt elvégezzük? Nem érdemes máshova áttelepíteni? A feladatok bővülésével nő a valószínűsége annak, hogy az anyagáramlás épületen belül, illetve az egyes épületek között nem a legkedvezőbb útvonalon történik.

- Why? Mi a célja a tevékenységeknek? A feladat végrehajtása után növeljük a vásárló elégedettségét? Növeli a működés hatékonyságát? Az egyes lépések dokumentálását sokan megkérdőjelezik, viszont az eredmények értékelése, a problémák feltárása során azonban bebizonyosodik ennek hasznossága.

- When? Ez az egyetlen sorrend, amiben a feladat elvégezhető? Több műszakban is lehet dolgozni? Van tartalékidő a rendszerben a felmerülhető váratlan helyzetek kezelésére?

- How? Ez a legjobb módja a tevékenység elvégzésének? A modern technológia megjelenésével az egyes tevékenységek sokkal megbízhatóbban és egyszerűbben elvégezhetők.

- How much? Érdemes egyszerre többet rendelni a mennyiségi kedvezmény elérése érdekében? Mekkora a legkedvezőbb termelési sorozatnagyság? Hány munkaeszközt, dolgozót alkalmazzunk az adott tevékenység elvégzésére?

Számos tanulmány vizsgálta az IT és a vállalati rugalmasság közötti kapcsolatot. Allen és Boynton (1991) szerint az informatika kifejezetten hozzájárulhat a rugalmassághoz, hiszen ezek lehetővé teszik a piaci változásokhoz való gyors reagálást [13]. 


\section{Folyamat-innovációs újszerű eszközei}

Ez a fejezet a napjainkban is zajló negyedik ipari forradalom három legjelentősebb fogalmának magyarázatát tűzte ki célul. Sokan úgy vélik, hogy az Internet of Things (IoT), a kiberfizikai rendszerek és a big data jelentős mértékben át fogjak alakítani a világot, új utakat nyitnak meg a termelési és szolgáltatási folyamatok fejlesztéséhez.

A rugalmas ellátás egyéb előfeltétele az, hogy hálózati alapúak együttműködés jöjjön létre az érintett partnerek között. Napjainkban a felhő alapú rendszerek elterjedésére, mobil alkalmazások és technológiák kihasználása elektronikus adatcserére (EDI) ad lehetőséget [14].

Az információs rendszerek, technológiák közé sorolhatjuk a rádiófrekvenciás azonosítást (RFID), a vezeték nélküli szenzorhálózatot (WSN), gépjármű kommunikációt (M2M), humán gépi interakció (HMI), web szolgáltatás stb. [15].

Vaidyanathan (2005) szerint a termelési technológiák kiválasztásakor a következő tényezőket kell figyelembe venni: az adatátvitel sebessége, megbízhatósága és folytonossága, automatizált adatátviteli folyamatok, megfelelő rendszerbiztonság, titkosítás és kódolás, adattárolás és nyomon követhetőség, valamint megfelelő számlázási és készletfelügyeleti szoftver alkalmazása [16].

Az informatikai beruházások használatakor nő a termelés, a bevétel és a nyereség, valamint magasabb minőség és teljesítmény érhető el ezen eszközök bevezetéskor. kapcsolódóan teljesítmény [14].

\subsection{Internet of Things (IoT)}

1999-ben Kevin Ashton használta először az „Internet of Things” kifejezést. Ennek számos magyar nyelvű megfelelőjét használjuk, de talán a „dolgok internete” kifejezés írja le a legjobban az elgondolás lényegét [17]. Az IoT teszi lehetővé a különféle eszközök (autó, biztonsági rendszer, kandalló, alkatrészek, anyagmozgató berendezések stb.) interneten vagy valamilyen hálózaton keresztül való elérését, valamint biztosítja bizonyos esetekben az eszközök közötti kommunikációt is. Az, hogy az elmúlt évtizedekben az adatok többségét az emberek rögzítették nagymértékben korlátozta az interneten elérhető adattípusokat és azok mennyiségét. Annak érdekében, hogy az emberiség tovább tudja fokozni használt rendszerek hatékonyságát, elengedhetetlen a felhasznált információkról való adatgyűjtés, illetve a gyűjtött adathalmaz alapján a rendszer működésbe való beavatkozása. Például elkerülhetjük a termelés leállását, ha a technológiai berendezések kulcsfontosságú alkatrészeit olyan speciális érzékelőkkel szereljük fel, amelyek a kialakuló problémát a meghibásodás előtt képesek jelezni és így időben beavatkozhatunk [18]. 2015. júliusában az eNET által végzett online kutatás megmutatta azokat az IoT megoldásokat, amelyeket a lakosság ismer és hasznosnak vél, ezek a következők:

- intelligens otthoni riasztó, amely üzenetet küld rendellenesség esetén,

- okosautó, képes a környezet érzékelésére és vészhelyzet esetén fékez vagy jelzést ad,

- okosmérő, valós idejű információt szolgáltat a gáz- és villamos áram-fogyasztásról és annak költségéről, ezt a szolgáltató is megkapja, így nem kell leolvasni, 
- online kassza, ez a pénztárgépek és a NAV rendszere közötti kommunikációt biztosítja.

Magyarországon az ágazatspecifikus informatikai beruházások pozitív hatással vannak a pénzügyi sikerre és az integráció mértékére, de nem a vállalkozások rugalmasságára. Az IT-beruházások javítják a folyamat hatékonyságát és a szolgáltatás színvonalát, de nem javítják az ügyfelek által elvárt rugalmasságot. Ez a tény többnyire a vállalkozások méretével függ össze, mivel az informatikai beruházásokat megvalósító vállalkozások általában nagyobbak [19].

\subsection{Kiberfizikai rendszerek}

A kiberfizikai rendszerek alkalmazását, az automatizálás és az informatika fejlődése, valamint a közöttük létrejött kapcsolat növekedése tette lehetővé. A kiberfizikai rendszerek olyan elektronikai eszközök, amelyek vezérléssel és hálózati kapcsolattal rendelkeznek [20]. Ezek a rendszerek szenzorok segítségével képesek a környezetükből adatokat gyűjteni, majd a helyzetük elemzését követően cselekedni. A kiberfizikai rendszerek a hálózatba kapcsoltak, illetve nagy részük egymással is összekötött, ezért valósítható meg a rajintelligencia, vagyis a közös stratégia alkalmazása a működésben, ami még hatékonyabb működést tesz lehetővé. A gyakorlatban számos olyan terület létezik, ahol a kiberifizikai rendszerek kialakítása a hatékonyság növelését eredményezheti:

- a közlekedésben a gépkocsik összekapcsolása csökkentené a légellenállást, a fogyasztást és a balesetek számát,

- a gyártórendszerek egyes elemeinek összekapcsolásával csökkenteni tudjuk a gyártási veszteségeket,

- ellátási láncok kialakításánál, működtetésénél.

\subsection{Big Data koncepció}

Az élet különböző területein (csillagászat, logisztika, kereskedelem stb.) hatalmas mennyiségű adat keletkezik, ezt mutatja az a tény is, hogy kétévente a világban keletkező adatmennyiség megduplázódik. Hasznos következtetéseket és új szolgáltatásokat hozhatunk létre ebből az óriási adathalmazból és az adatok közötti korrelációkból. Ilyen szolgáltatás lehet például az a szoftver, amely a repülőjegyek árának előrejelzésére szolgál, megadja a megfelelő vásárlási időpontot a korábbi jegyvásárlások alapján, anélkül, hogy ismernénk a háttérben futó számítási metódust [21]. A big data lényege az előrejelzés, vagyis valószínűségeket határoz meg matematikai módszerekkel, eljárásokkal nagy mennyiségű adatból. A big data koncepcióval nagy valószínűséggel tudunk majd megfelelő döntéseket hozni a nagy mennyiségű adatra támaszkodva, akár anélkül, hogy ismernénk az ok-okozati összefüggéseket. Ez egyesek szerint jelentős mértékű változást fog okozni a jövőben.

Ebben a fejezetben ismertetett kifejezések szoros kapcsolatban vannak egymással, vagyis nem beszélhetünk sem kiberfizikai rendszerekről, sem big data-ról az IoT nélkül. 


\section{5. Új intelligens logisztikai megoldások kidolgozása}

Azokat az eszközöket/(rész)rendszereket nevezzük intelligens logisztikai megoldásoknak, amelyek képesek a külső környezeti változásokra reagálni. Ezen megoldások használatával és fejlesztésével lehetőség nyílhat a veszteségek nagymértékű csökkentésére. A veszteségek csökkenését az eredményezi, hogy a feladatok elvégzéséhez szükséges reakcióidő lerövidül, illetve növekszik az emberi- és gépi erőforrások kihasználtsága azáltal, hogy a rendszer objektumai (pl.: a forrás és a nyelő objektumok, a személyzet, anyagmozgató eszközök stb.) között az optimalizált együttmúködés növekszik. A termelési területen jelenleg is alkalmaznak ilyen intelligens logisztikai megoldásokat, melyek a következők:

- Intelligens azonosítóeszközök: ezek automatikus üzeneteket küldenek a külső környezet kedvezőtlen változásáról például, ha a hőmérséklet vagy páratartalom a megszabott határérték alá csökken.

- Intelligens technológiai berendezés: az automatizált megmunkálás az azonosítóeszköz adatai alapján történik vagy a meghibásodás előrejelzése szenzorok segítségével.

- Intelligens minőség-ellenőrzés: amikor a berendezés a szükséges ellenőrzéseket a terméken elhelyezett RFID chip adatok alapján hajtja végre.

- Intelligens anyagmozgató berendezés: automatikus működés a környezeti adatok alapján.

- Intelligens raktár: érzékelők segítségével észleli a készletfogyást és automatikus rendelésfeladás történik

Az ipar 4.0 a gyártási rendszerek kialakítására és múködtetésére egyaránt jelentős hatással lesz. Az előrejelzések alapján a következők várhatók:

- Megvalósulhat a különféle eszközök (anyagmozgató gépek, technológiai berendezések, alkatrészek stb.) és a központi egység(ek), valamint az egyes eszközök közötti kommunikáció is megvalósulhat, így a decentralizált önvezérlés fogja felváltani az eddig alkalmazott központi vezérlést.

- A merev, komplex döntéshozatal felcserélődik a valós idejű szimuláción alapuló döntésekre.

- A technológiai berendezések rugalmasságának növekedése eredményezi (pl.: 3D nyomtatás), hogy az eddig alkalmazott előre tervezett termelési rendszereket a modularizáción alapuló termelés bővülések jellemzik majd.

- A jelenleg használt passzív munkadarabokat lecserélik az intelligens munkadarabokra, melyek képesek lesznek arra, hogy befolyásolják a környezetüket a rájuk programozott információk alapján.

- Valószínűsíthető, hogy új üzleti modellek jelennek meg a logisztikai rendszerekről gyűjtött nagy mennyiségű adatok feldolgozása nyomán. Például a termelés kiesés kockázata nagymértékben mérsékelhető lesz, mivel az elvégzett feladat adatok alapján nagy pontossággal előre jelezhető az adott típusú berendezés meghibásodása vagy a dolgozó megbetegedése. 


\section{Módszerek használata}

A módszerek sorrendje egy ciklus köré szerveződik, amit PDCA (plan - do - check - act), azaz tervezés végrehajtás - ellenőrzés - cselekvés ciklusnak szoktak nevezni. A fejlesztési lépések ciklusa a 3. ábrán jól látható. A tervezés szakaszban meg kell keresni a felülvizsgálat módját és helyét, majd végre kell hajtani a felmerült ötleteket. Ezt követően ellenőrzésképp meg kell nézni, hogy a kifejlesztett művelet egyes jellemzői hogyan alakulnak, majd a folyamatot mindennapos rutinná kell tenni. Ha egy hibát megoldottunk, azt követheti a következő megoldása, viszont a kiindulás már magasabb szintről történik. A folyamat fejlesztésének lépései egymást követik, egyik a másikra épül, így innen kapta a folyamatos fejlesztés elnevezést [22].

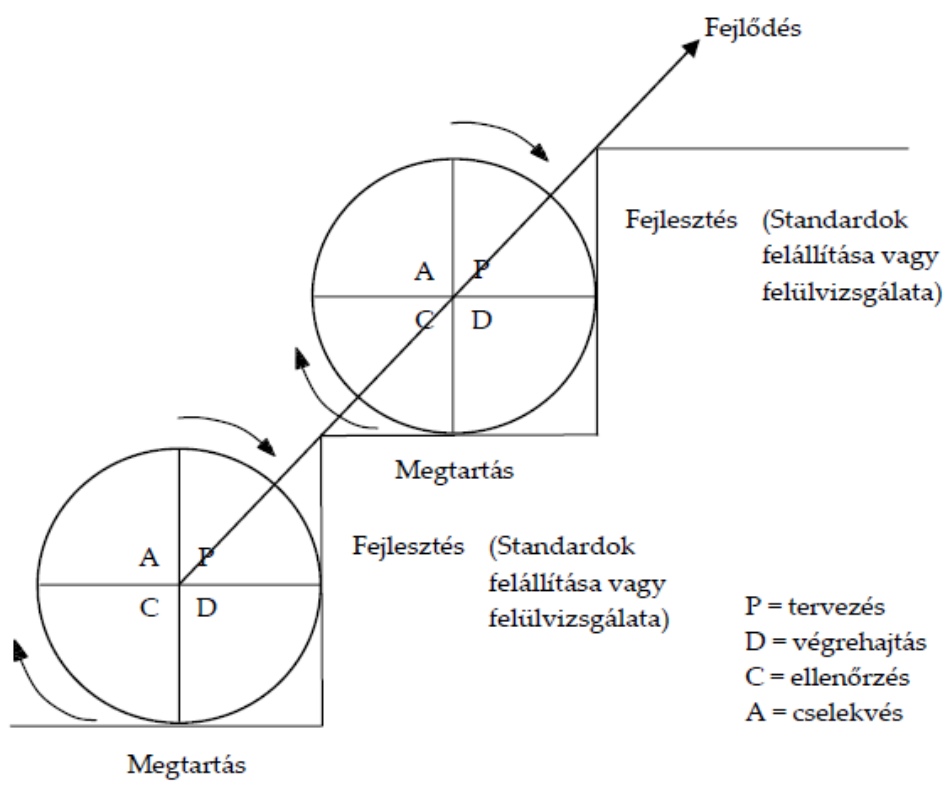

3. ábra: A fejlesztési lépések egymásra épülése

Forrás: Chikán - Demeter, 2003

A termelő vállalkozások termékeinek minősége és jövedelmezősége javult az új informatikai rendszerek használatakor [23].

\section{Következtetések, javaslatok}

A felsorolt módszerek csak egy részét képviselik a termelési folyamat fejlesztésének, viszont ennyi is elég annak érzékelésére, hogy a fejlesztés során nincs szükség komplex módszerekre. A mindenki által használható, egyszerű eszközök ereje abban rejlik, hogy mindenki képes legyen megtanulni, megérteni és alkalmazni, majd a részfolyamatok elvégzése után gyors visszacsatolást adni. A kutatás során bemutatott eszköztár nem csak a termelésben használható. Az értékteremtő folyamat minden egyes része felbontható elemeire, meghatározható a rutinszerű cselekvések sorrendje, így gyorsan elemezhetők a problémák okai. 
A gyártórendszerek megvalósításában, működtetésében a 4. ipari forradalom nyújtotta lehetőségek számottevő változást hoztak. A kiberfizikai rendszerek és az IoT megjelenése a gyártási, logisztikai rendszerek hatékonyabb müködtetését és a folyamatos fejlesztést tették lehetővé. A big data megjelenése elősegítette az olyan adatállományok feldolgozását, amik annyira komplexek és olyan nagy méretűek, hogy elemzésük a hagyományos eszközökkel körülményes. A gépek hálózati kommunikációja, valamint a gyártásban áramló anyagok nyomkövetéséből származó információk, a gyártási folyamatok szélesebb körű optimalizálására adnak lehetőséget.

\section{Hivatkozások}

[1] Weill, P. - Subramani, M. - Broadbent, M. (2002) IT Infrastructure for Strategic Agility, In: MIT Sloan Management Review, 44/1. pp. 57-65. October 2002.

[2] Wu, F. - Yeniyurt, S. - Daekwan, K. - Cavusgil, T. (2006) The Impact of Information Technology on Supply Chain Capabilities and Firm Performance: A Resource-Based View, In: Industrial Marketing Management, 35/4. pp. 493-504. https://doi.org/10.1016/j.indmarman.2005.05.003

[3] Kocsi, B. - Oláh, J. (2017) Potential connections of unique manufacturing and industry 4.0, In: Logforum, 13/4. pp. 389-400. http://dx.doi.org/10.17270/J.LOG.2017.4.1

[4] Sharma R.K. - Kumar D. - Kumar P. (2015) Systematic failure mode effect analysis (FMEA) using fuzzy linguistic modelling, In: International Journal of Quality and Reliability Management, 22/9. pp. 986-1004. http://dx.doi.org/10.1108/02656710510625 248

[5] Stamatis, D.H. (2003) Failure Mode Effect Analysis: FMEA from Theory to execution. American Society for Quality, Quality Press, Milwaukee.

[6] Shang, K. - Feng, F. - Ke, L. - T.S. Chan, F. (2016) Comprehensive Pareto Efficiency in robust conterpart optimization, In: Computers \& Chemical Engineering, 94, pp. 75-91. https://doi.org/10.1016/j.compchemeng.2016.07.022

[7] Chikán, A. - Demeter, K. (2003) Az értékteremtő folyamatok menedzsmentje, AULA.

[8] Visveshwar, N. - Vishal, V. - Venkatesh, V. - Vimal, S. - Pragadish, K. (2017) Application of Quality Tools in a Plastic Based Production Industry to achieve the Continuous Improvement Cycle, In: Quality access to success, 18/157.

[9] Prístavka, M. - Kotorová, M. - Savov, R. (2016) Quality Control in Production Processes, In: The Scientific Journal for Agricultural Engineering, The Journal of Slocak University of Agriculture in Nitra, 19/3. https://doi.org/10.1515/ata-2016-0016

[10] Nagyova, A. - Palko. M. - Pacaiova, H. (2015) Analysis and identification of nonconforming products by 5W2H method, In: 9th International Quality Conference, Center for Quality, Faculty of Engineering, University of Kragujevac

[11] PwC Magyarországi Vezérigazgató Felmérés (2017), https://www.pwc.com/hu/hu/ceo/2017.html Letöltés: 2018.03 .18 
[12] Oláh, J. - Karmazin, Gy. - Pető, K. - Popp, J. (2017) Information technology developments of logistics service providers in Hungary, In: International Journal of Logistics Research and Applications, pp. 1-13. https://dx.doi.org/10.1080/13675567.2017.1393506

[13] Allen, B.R. - Boynton, A.C. (1991) Information Architecture: in Search of Efficient Flexibility, In: Mis Quarterly, 15/4. pp. 435-445.

[14] Oláh, J. - Zéman, Z. - Balogh, I. - Popp, J. (2018) Future challenges and areas of development for supply chain management. In: LogForum 14/1. pp. 127-138, 2018, http://dx.doi.org/10.17270/J.LOG.2018.238, p-ISSN 1895-2038, e-ISSN 1734-459X

[15] Atzori, L. - Iera, A. - Morabito, G. (2010) The internet of things: a survey, In: Computer Networks, 54/15. pp. 2787-2805. https://doi.org/10.1016/j.comnet.2010.05.010

[16] Vaidyanathan, G. (2005) A Framework for Evaluating Third-Party Logistics, In: Communications of the ACM, 48/1. pp. 89-94. doi: 10.1145/1039539.1039544

[17] Shrouf, F. - Ordieres, J. - Miragliotta, G. (2014) Smart factories in Industry 4.0: A review of the concept and of energy management approached in production based on the Internet of Things paradigm, In: Industrial Engineering and Engineering Management (IEEM), 2014 IEEE International Conference on, doi: 10.1109/IEEM.2014.7058728

[18] Whitmore, A. - Agarwal, A. - Li Da Xu (2014) The Internet of Things - A survey of topics and trends, In: Information Systems Frontiers, 17/2. pp. 261 - 274. https://doi.org/10.1007/s10796-014-9489-2

[19] Oláh, J. - Máté, D. - Popp, J. (2017) An Examination of Servitization as a Breakthrough Succes Factor alnog the Supply Chain, SEA-Practical Application of Science. 5/15. pp. 373-379. http://spas.seaopenresearch.eu/online-first.html

[20] Lee, J. - Bagheri, B. - Hung-An, K. (2015) A Cyber-Physical Systems architecture for Industry 4.0based manufacturing systems, In: Manufacturing Letters, 3, pp. 18-23. https://doi.org/10.1016/j.mfglet.2014.12.001

[21] Zhong, R. - Lan, S. - Chen Xu, - Dai, O. - Huang, G. (2016) Visualization of RFID-enabled shopfloor logistics Big Data in Cloud Manufacturing, In: The International Journal of Advanced Manufacturing Technology, 84/1-4. pp. 5-16. https://doi.org/10.1007/s00170015-7702-1

[22] Mitreva, E. (2009) Methodology for improvement of business processes. Central and Eastern European Online Library, 3/3. pp. 177-190.

[23] Stank, T. - Crum, M. - Arango, M. (1999) Benefits of Interfirm Coordination in Food Industry Supply Chains, Journal of Business Logistics, 20/2. pp. 1-21. 